Pawel J. Dąbrowski

Zakład Procesu Zarządzania

Wyższa Szkoła Informatyki i Zarządzania w Rzeszowie

\title{
A jednak win-win ${ }^{1}$ : pragmatyka etyki przedsiębiorczości, czyli nowe spojrzenie na negocjacje
}

\section{Czy win-win działa?}

Pytanie, „czy etyczny biznes jest zgodny, czy też sprzeczny z naturalną logiką”, w literaturze etyki nieczęsto jest zadawane wprost, ale jest pytaniem fundamentalnym, na które muszą sobie odpowiedzieć przedsiębiorcy. Bo czy tak rzadki jest przypadek, który przydarzył mi się osobiście, że młody człowiek z Polski, myślący o karierze w biznesie, powiada: „na początek trzeba kogoś "stuknąć«".

Niedawno na jednej ze stron internetowych trafiłem na interesujące stwierdzenie: „Obecnie najbardziej wypromowany i najpopularniejszy jest system negocjacji, zwany negocjacjami typu win-win (...) oparty na przekonaniu, że zwyciężyć mogą obie strony. System ten coraz częściej przestaje się sprawdzać (podkreślenie autora). (...) Coraz częściej duże koncerny zachowując miły ton rozmów, wykorzystują swoją siłę, aby nie iść na żadne realne ustępstwa" (Michalik 2007). Co zabawne, autorka jednocześnie ma rację i nie ma racji. Ma rację, bo teoria win-win naiwnie zachwalana jest jako niezawodna filozofia, ale bez przełożenia na model funkcjonowania firmy. W rezultacie często nie ma ona pokrycia w rzeczywistości. Ma autorka rację, bo praktyka wielu firm często bywa nastawiona na maksymalizację krótkoterminowego zysku, nawet kosztem innych. Rzeczywiście, wiele firm tak postępuje, zwykle jednak płacą za to wysoką cenę w dłuższej perspektywie. Autorka nie ma racji, bo inne firmy skutecznie budują wzajemnie korzystne relacje z dostawcami, pracownikami i klientami, i odnoszą z tego istotne korzyści w dłuższej prespektywie.

Czasem nawet cena za egoistyczne postępowanie jest ceną najwyższą: na przełomie lat 2006 i 2007 prasa doniosła o sprawie niemieckiego przedsiębiorcy, który do produkcji używał przeterminowanego mięsa. Gdy wyszło to na jaw - popełnił samobójstwo. Na początku 2007 r. prasa doniosła o śmierci Grobelnego - negatywnego bohatera jednej z największych polskich afer. I choć nieomal uszło mu wszystko na sucho, to skończył marnie. Czy jakikolwiek zysk wart jest tej ceny?

Zacznijmy od dostawców i powiedzmy sobie jasno: wiele firm - dużych i małych, w Polsce i na Zachodzie - wykorzystuje ich jak tylko może, np. jako źrodło taniego kredytu, nie płacąc jak długo można i płacąc jak najmniej. Dostawcy wykorzystywani są również jako ,amortyzator ryzyka"; są zmuszeni do utrzymywania zapasów lub gotowości produkcyjnej na rzecz odbiorcy.

${ }^{1}$ Win-win jest terminem zaczerpniętym z teorii gier, gdzie oznacza jeden z czterech podstawowych wyników gry, gdy obie strony wygrywają. Pozostałe to lose-lose (obie strony przegrywają), win-lose (ja wygrywam, oni przegrywają) i lose-win (ja przegrywam - oni wygrywają). W szerszym znaczeniu, przyjętym w ekonomii, psychologii i teorii negocjacji, termin ten oznacza kierunek myślenia oparty na przekonaniu, że w dłuższej perspektywie znacznie korzystniejsze są kontrakty, na których obie strony zyskują, w przeciwieństwie do sytuacji, gdzie zwycięstwo w negocjacjach opiera się na wykorzystaniu drugiej strony. 
Podobnie jest z relacjami pracowniczymi. Wielkie firmy, mimo deklaratywnych stwierdzeń typu „ludzie to nasz najcenniejszy majątek”, często posuwają się do masowych zwolnień, dostrzegajac jedynie pozbycie się zbędnych kosztów.

Wreszcie, choć hasło ,troska o klienta" nie schodzi marketingowcom z ust, wiele firm szybko porzuca rynki, które wydają się mało opłacalne lub - w imię redukcji kosztów - obniża standard usług, tak że klienci sami odchodzą. Przykładem może być telefoniczna firma US West, która świadomie, wbrew zobowiązaniom, obniżyła standard świadczonych usług dla biedniejszych, mniej opłacalnych rejonów. Przyniosło to szybkie oszczędności: wartość giełdowa firmy gwałtownie wzrosła i została ona korzystnie sprzedana za 45 mld dolarów. Choć korporacja musiała zapłacić 50 mln dolarów odszkodowania, dzięki korzystnej sprzedaży firmy jej chief executive Sol Trujillo otrzymał premię w tej samej wysokości - 50 mln dolarów (Washington 2005).

I nie jest to bynajmniej kwestia, jak niektórzy głosza, ,tych złych wielkich korporacji”. Małe biznesy też nie lepiej sie zachowują: niektórzy mechanicy regularnie zawyżają rachunki, dentyści wstawiają plomby wypadające po roku-dwóch i trzeba robić koronkę... Niektórzy doradcy finansowi polecają złe inwestycje tylko dlatego, że ich promotorzy płacą im ,na boku” wysokie prowizje.

Niektóre wojownicze związki zawodowe „w imię solidarności pracowniczej” nie pozwalają na usprawnianie procesu produkcyjnego, tam gdzie wiąże się to z eliminacją miejsc pracy. Na przykład, w przededniu wielkiej komputeryzacji potężny Brytyjski Związek Drukarzy upierał się przy utrzymaniu stanowiska obsługi wyłącznika bezpieczeństwa nowej automatycznej prasy drukarskiej - mimo że tego wyłącznika już nie było (Shawcross 1997)!

Wydaje się, że z win-win jest jak ze zdrowym trybem życia: niby każdy wie, jak to jest (prawie), każdy deklaruje, że popiera... A praktyka? Coż - bywa różnie ${ }^{2}$. Rzecz w tym, że nie wystarczą gołosłowne deklaracje czy akceptacja „tak w ogóle” filozofii win-win. Żeby ją w praktyce ralizować, organizacje muszą zredefiniować swoje stosunki z partnerami i swoje podejście do negocjacji.

\section{Jakie są skutki odrzucenia win-win?}

Firmy, które stosują strategię eksploatacji swoich partnerów - klientów, dostawców czy pracowników - z zasady odnoszą pewne krótko- bądź nawet średnioterminowe korzyści. Gorzej z perspektywą długoterminową. Przykład? Australijskie banki zaczęły systematycznie robić oszczędności przez redukcję zatrudnienia, obniżając jakość obsługi klientów indywidualnych i małych przedsiębiorstw oraz likwidując oddziały w małych miasteczkach. Najpierw zaowocowało to falą niechęci do banków. Po pierwszym wywiadzie prasowym, który obwieścił wejście na rynek alternatywnego pożyczkodawcy, niechęć ta zmaterializowała się długą kolejką chętnych do zmiany instytucji finansowej. Niski standard obsługi bankowego oligopolu wytworzył próżnię, w którą weszła rzesza niezależnych brokerów i liga alternatywnych instytucji pożyczkowych. Obecnie, skutkiem tego, banki chcąc nie chcąc, muszą zdać się na niezależnych brokerów i godzić się z dużo niższymi marżami. O ile bowiem pożyczki zorganizowane w oddziale bankowym dawały marże brutto w wysokości $0,59 \%$, to te rozprowadzane przez brokerów przynoszą marżę wielokrotnie niższą: zaledwie-0,07\% (Swift 2007).

Inna kwestia: wcześniej banki zniszczyły swoją reputację wśród małego biznesu, obecnie starają się ją usilnie odrobić. Próżnia obsługi finansowej małych miasteczek dała tymczasem

\footnotetext{
${ }^{2}$ Jako społeczeństwa też nie jesteśmy bez winy: na skutek słabości negocjacyjnej nauczyciele w wielu krajach - w tym w Polsce, Stanach Zjednoczonych i Australii - są nisko opłacani. W oczywisty sposób odbija się to na poziomie nauczania, bo najlepsi uciekają do innych zawodów, a ci, którzy zostają żyją w stanie ciągłej frustracji.
} 
szansę prowincjonalnemu Bendigo Bank, który - współpracując efektywnie z lokalnymi społecznościami - osiagnął niespotykaną na dojrzałym rynku stopę wzrostu, przez wiele lat nieschodzącą poniżej liczby dwucyfrowej, a osiaggającą w niektórych latach nawet $36 \%$. W tym samym okresie Commonwealth Bank of Australia stracił ogromną część udziału w rynku - spadł z około $20 \%$ do $12,9 \%$ (Searle 2007).

Podobna kwestia: australijscy agenci nieruchomości nadużywali systematycznie zaufania swoich klientów, każąc im płacić za ekstrawaganckie ogłoszenia; a znaczna część tych pieniędzy okrężną drogą wracała do agentów. Skutkiem irytacji klientów, którzy wcześniej czy później się o tym dowiadywali, było powstanie niezależnych systemów sprzedaży. Dało to odskocznię alternatywnemu systemowi Neila Janmana, który z ataku na owe oszukańcze praktyki uczynił dźwignię swojej niezwykle skutecznej strategii marketingowej (Janman 2000).

Podobnie ma się sprawa z relacjami firma - pracownicy. Z doświadczeń lat 70. XX w., gdy zdecydowane redukcje nadmiernie rozbudowanych korporacyjnych biurokracji przynosiły nie tylko oszczędności, ale i podniesienie efektywności funkcjonowania firm, wiele rynków kapitałowych wyciagnęło pochopny wniosek, że pracownicy są jedynie balastem. Spowodowało to falę zbyt daleko idących redukcji zatrudnienia, stratę ,,pamięci organizacyjnej” i obniżenie morale. Te zaś korporacje, które potrafiły właściwie spożytkować talenty i inteligencję pracowników, osiagają nieporównanie lepsze rezultaty.

A co z wykorzystywaniem dostawców? Na bardzo konkurencyjnych rynkach odbiorcy szantażują swoich dostawców, „wyduszając” z nich ceny na granicy opłacalności, a czasem poniżej tej granicy. Postępują tak niektóre wielkie korporacje przemysłowe i wielkie domy towarowe, zarówno w Polsce, jak i na Zachodzie. Oczywiście, uzyskane niższe ceny od dostawców to nie tylko bieżące zyski, to także lepsza pozycja konkurencyjna: możliwość dawania upustów, rabatów, wydawania więcej na marketing. Problemy zaczynają się jednak wtedy, gdy „,przyduszeni” dostawcy smi zaczynają oszczędzać na wszystkim, na czym oszczędzić można. Odbija się to na jakości: zaniedbanie małej części samochodowej za 15 dolarów powoduje czasem konieczność przeglądu całej serii samochodów, co kosztuje 150 lub 2000 dolarów, nie licząc irytacji klienta.

Może to nawet zagrozić egzystencji samych firm. Tak się stało np. w 2006 r. w Australii, gdzie jeden z większych dostawców części samochodowych zbankrutował, co przyniosło spore kłopoty finalnym producentom.

Zwykle kłopoty te są mniej widoczne: właściciele po prostu przestawiają się na poszukiwanie bardziej atrakcyjnych rynków, a zaniedbana dotychczas produkcja ledwie zipie, pozbawiona bodźców rozwoju i innowacyjności.

\section{Czy można inaczej?}

Wróćmy do początkowego cytatu: nie zgadzam się ze stwierdzeniem, że podejście win-win „coraz częściej przestaje się sprawdzać”. Być może po prostu niektóre firmy spokojnie tolerowały organizacyjną schizofrenię, kiedy na szkoleniach i w misji firmy mówiło się o radosnej kooperacji, a w praktyce starano się wycisnąć wszystkie soki ze wszystkich - dostawców, pracowników i klientów. Obecnie być może zamierzają one pogodzić filozofię działania z tym, co zawsze praktykowały, a co postrzegają jako „,twardą grę rynkową”.

Inne firmy jednak dążą jednoznacznie do praktyki etycznego biznesu: w ostatnich latach rozwiną się ruch społecznej odpowiedzialności firm (Corporate Social Responsibility) i społecznie odpowiedzialnych inwestycji (Socially Responsible Investments) - wystarczy zajrzeć np. na stronę Forum Odpowiedzialnego Biznesu - www.odpowiedzialnybiznes.pl.

Takie podejście to nie tylko idealistyczna teoria. Sprawdza się ono w praktyce. Australijska wytwórnia piwa Lion Nathan, w której właśnie niskie morale w firmie postrzegano jako podstawową 
przyczynę marazmu i upadku, uczyniła z podejścia etycznego dźwignię odnowy firmy. Zdefiniowawszy swoją misję jako ,przyczynianie się do radości życia”, zdecydowano np. wycofać automaty hazardowe z pubów - ze względu na ich szkodliwość społeczna. Co ciekawe, ten eksperyment, zbudowany na etycznym fundamencie, całkowicie się powiódł pod względem ekonomicznym. Po wprowadzeniu programu korporacja przez kolejnych pięć lat osiągała systematyczny wzrost poziomu zysków, z poziomu bliskiego zeru do ponad $200 \mathrm{mln}$ dolarów w $2004 \mathrm{r}$. (Tandukar 2005).

Wartość win-win i sprawdzonego dostawcy rozumie też dobrze polski cukiernik Robert Dybalski z Łodzi. Mówi on: „Jajka, których zamawiam rocznie półtora miliona, mógłbym kupować dużo taniej niż obecnie, ale biorę je od jednego, od lat sprawdzonego hurtownika, i nigdy nie miałem problemu z zatruciami pokarmowymi” (Kamiński 2006).

Klasycznym przykładem kooperacyjnych relacji z pracownikami i dostawcami jest Toyota (Langfield-Smith 1998). Jej podejście jest korzystne zarówno dla dostawcy, jak i dla odbiorcy: owocuje wyższą jakością produktu, wyższą wydajnością, redukcją kosztów i czasu cyklów produkcyjnych. Bywa, że współpraca idzie dalej: gdy niedawno zakład jednego z jej dostawców w Melbourne padł ofiarą pożaru, powszechnie spodziewano się, że Toyota go porzuci. Nastąpiło jednak coś przeciwnego: Toyota nie tylko wsparła dostawcę w procesie odbudowy potencjału, ale przysłała grupę swoich inżynierów, by pomóc podnieść jakość produkcji (Thompson 2007).

Kooperacyjne podejście do pracowników owocuje tysiącami drobnych usprawnień, dzięki którym Toyota zdołała zredukować w ostatnim roku czas montażu samochodów o 5,5\% (Geng 2007). Dla porównania: GM, stosując podejście podobne pod względem technicznym, osiagnął wyniki istotnie mniejsze - tylko 2,5\% redukcji czasu montażu. Choć średnia płaca za godzinęjest zbliżona, to efektywny koszt roboczogodziny w Toyocie wynosi 48 dolarów, a w GM - prawie 74 dolary. Antagonistyczne stosunki ze związkami zawodowymi i ich opór przeciwko wprowadzaniu usprawnień powoduje, że gdy dzisiaj Toyota potrzebuje niecałe 28 godzin na zmontowanie jednego samochodu, to GM zużywa na to ponad 34 godziny. W rezultacie Toyota zarabia średnio 1488 dolarów na samochodzie, a GM traci na nim 2331 dolarów. Czy można się zatem dziwić, że w ciagu ostatniego dziesięciolecia akcje GM spadły o 56\%, a akcje Toyoty wzrosły o 35\%? Że udział GM w rynkach światowych spadł z 14,6\% w 2002 r. do obecnych 14,2\%, a udział Toyoty w tym samym okresie wzrósł z 10,6\% do 12\%? Czy można się dziwić, że brak win-win w stosunkach pracowniczych przyczynił się do utraty 30 tysięcy miejsc pracy w GM, a Toyota planuje przyjmowanie nowych pracowników?

Przykład Toyoty jest istotny dla zrozumienia znaczenia kooperatywnych relacji pomiędzy partnerami w biznesie. Przykład firmy Google i jej idyllicznych wręcz relacji pracowniczych może być kwestionowany za pomocą argumentu (niesłusznego), że cały ich sukces opiera się na dobrym pomyśle i dynamicznie rozwijającym się rynku. Wiele sukcesów w biznesie może być (słusznie lub niesłusznie) przypisywanych dobremu pomysłowi, koniunkturze czy innym przypadkowym czynnikom.

Sukces Toyoty, ze względu na długi czas trwania, rozległa gamę produktów i globalność konkurencji w branży motoryzacyjnej, jest argumentem nie do zbicia. To właśnie dało prawo autorom Competing for the Future (Hamel, Prahalad 1994), jednej z najważniejszych pozycji literatury zarządzania ostatnich dwudziestu lat, powiedzieć: „Lekcje z doświadczeń i sekret Toyoty są proste: ona tworzy więzi partnerskie pomiędzy jednostkami i firmami, które wspierają zasadę »Działaj w harmonii, pracuj razem, w jednym kierunku«. Jest to w ostrym kontraście z większością firm, które są »zdezorganizowane, gdzie nikt nikomu nie ufa i nikt nie zostaje dostatecznie długo, by ufać i zaskarbić sobie zaufanie innych «". Wreszcie, wiemy że troska o satysfakcję klienta to nie tylko dobre hasło marketingowe, ale i najlepszy prognostyk długofalowego 
sukcesu firmy. Twierdził tak od dawna Tom Peters (1992), a jego opinię potwierdzają najnowsze badania przeprowadzone na uniwersytecie Michigan (Hart 2007). Stwierdzono tam m.in., że wartość akcji firm o najwyższych wskaźnikach satysfakcji konsumentów wzrosła średnio o 145,5\% w ciagu pięciu lat, przy średniej giełdowej wzrostu wartości akcji według Standard $\&$ Poor $500-38,7 \%$.

\section{Jak można to zrobić?}

Po pierwsze - wizja. Przede wszystkim firma musi wykreować praktyczną wizję przełożenia filozofii win-win na wielorakie korzyści firmy i wszystkich wewnętrznych i zewnętrzych interesariuszy. Inaczej to nie działa - w najlepszym wypadku będzie to pełne rozdarcia robienie dobrych uczynków (bo poświęcamy własne zyski, a czasem konkurencyjność), a w najgorszym - trącące hipokryzją głoszenie pięknych teorii, w które nikt nie wierzy.

Filozofia win-win musi się przekładać na postępowanie dnia powszedniego - kulturę firmy. W praktce może to wyglądać prosto. Pamiętam relację uczestnika jednego z pierwszych w Polsce treningów negocjacyjnych, który pracował w polskim przedstawicielstwie szwedzkiej firmy. Opowiadał nam, że mógł łatwo naciagnnąć klienta na 10 tysięcy dolarów, ale szef powiedział mu: „u nas tego się nie robi”.

Za filozofią win-win muszą stać praktyczne strategie, dzięki którym piękna idea będzie się przekładać na system organizacyjny. Ogromny potencjał zredefiniowania negocjacji tkwi w przekszałceniu czystych transakcji handlowych we wspólne poszukiwanie synergii firm, w poszukiwanie możliwości kreowania nowej wartości i bardziej efektywnych sposobów działania. Pomocne jest przejście od tradycyjnego marketingu 4P (Product, Price, Promotion, Place) do marketingu przedsiębiorczego 4C (Clients' Benefits, Total Customer Cost, Communication, Client Convenience). Wtedy to, myśląc o produkcie, koncentrujemy się nie tylko na użytecznościach klienta jako skutecznej metodzie sprzedaży, ale wspólnie z klientem staramy się zredefiniować produkt i jego sposób użytkowania dla optymalizacji korzyści obu stron (przechodzimy wtedy do Creation of Clients' Benefits). Nie tylko zastanawiamy się nad własną strategią cenową Price (czy to penetracja rynku, czy zbieranie śmietanki), ale i wspólnie analizujemy całościowy koszt użytkowania produktu ze strony klienta (Total Customer Cost). Nowy Communication mix to nie tylko Promotion - zespół narzędzi do zawrócenia w głowie klientowi, ale i wypracowanie efektywnych sposobów komunikowania się w obie strony i wspólnego komunikowania się z otoczeniem: nowymi i potencjalnymi klientami, inwestorami, bankami.

Logistyczne zagadnienie Place, skoncentrowane do tej pory na optymalizacji wewnętrznych operacji, rozszerzamy do Client Convenience, optymalizując od strony klienta dostęp do produktu czy usługi (a przede wszystkim do klarownie zdefiniowanej użyteczności). Skoordynowane badania i rozwój, tak jak i system just in time, są naturalnymi przejawami takiego podejścia. Nie jest to jednak możliwe, jeśli negocjacje z kontrahentami są zastrzeżone dla wąskiej grupy handlowców sprzedaży i zaopatrzenia. Zredefiniowanie negocjacji wymaga wykorzystania potencjału intelektualnego wielu osób, wymaga też inwestycji w kształcenie i rozszerzenia obiegu informacji.

Efektywny system negocjacji w organizacji musi być przemyślany i skoordynowany, od wizji, przez system organizacyjny, do szkolenia i rozliczania pojedynczego negocjatora. Inaczej indywidualne wysiłki nie tylko nie będą optymalnie ulokowane, ale czasem mogą być wręcz ,przeciwskuteczne". Przykłady? Kiedyś współpracowałem z jedną z czołowych polskich firm konsultingowych nad ratowaniem upadającej fabryki mebli. Przyglądaliśmy się strategii marketingowej i systemowi finansowania. Pewną kwestię uświadomiłem sobie z pełną wyrazistością dopiero teraz. Znaczna część krajowej sprzedaży była tak zorganizowana, że kierowca zaopatrujący 
mniejsze sklepy był jednocześnie sprzedawcą. Problem w tym, że opłacany był on - zgodnie z logiką systemu finansowego - w momencie zaksięgowania sprzedaży. Rzeczywista płatność (wpływ gotówki do firmy) następowała dużo później lub nie następowała nigdy. Ale komiwojażer nie był tym zainteresowany. Jeśli zostawił w sklepie następny zestaw mebli (i fakturę), i tak dostawał swoją prowizję, nawet jeśli dany sklep zalegał z płatnościami od pół roku.

Niedawno dowiedziałem się, że sieci kolportażowe w Warszawie ignorują sugestie sprzedawców w kioskach dotyczące zaopatrzenia w czasopisma, bo mają ,własne badania marketingowe”. W Australii też nie zawsze jest lepiej - zmorą niezależnych brokerów finansowych jest niedotrzymywanie terminów przez banki, co powoduje irytację klientów, a nawet utratę kontraktów.

Wprowadzenie win-win do codziennej praktyki będzie czasem wymagać zakwestionowania istniejącego systemu. Często bowiem istniejący układ premiuje kontrahenta za działanie na niekorzyść firmy - np dekorator, architekt czy menedżer projektu konstrukcyjnego opłacani bywają procentowo od wartości projektu. W efekcie im wyższe koszty ,zrobią”, tym większe będą ich dochody.

Widać jednak, jak dużo w tej dziedzinie jest do zrobienia i jak dużo firmy będą mogły uzyskać, redefiniując swoje podejście do negocjacji. Raz jeszcze za przykład może posłużyć Toyota: GM wydaje na opiekę zdrowotą 1525 dolarów na jeden samochód, Toyotę kosztuje to jedynie 201 dolarów.

Uprawianie (lub nieuprawianie) strategii win-win ma więc kluczowe znaczenie dla długofalowych wyników przesiębiorstw i korporacji. Historia niesławnego Ala „The Chainsaw” Dunlopa daje dużo do myślenia: wprowadził on w korporacji Sunbeam znaczne oszczędności, brutalnie redukując zatrudnienie i ,wyciskajacc" kooperantów. Zgarnął ogromną premię za wyniki, ale doprowadził firmę na skraj bankructwa, a inwestorów do rozpaczy. Dlatego też stać się powinien obiektem zainteresowania nie tylko kierownictw przedsiębiorstw, ale także rad nadzorczych i funduszy inwestycyjnych.

Ktoś mógły powiedzieć: to już nie negocjacje, ale strategia biznesu. I chyba właśnie w tym tkwi istota rzeczy. Może właśnie o to chodzi, że wiedza czerpana z każdej z dyscyplin funkcjonalnych (jak marketing, finanse czy elektronika) może być najefektywniej wykorzystywana, gdy jest w pełni zintegrowana ze strategią biznesu.

Podsumowując, można stwierdzić, że dobre wyniki daje przegląd wpływu relacji między stronami w stosunkach biznesowych. Wskazują one jednoznacznie, że etyczne, obustronnie kooperacyjne strategie są nie tylko pożądane społecznie, ale również korzystne w długofalowym wymiarze finansowym.

\section{Literatura}

1. Dyer J.H., Ouchi W.G., 1993, Japanese-style partnerships: giving companies a competitive edge, Sloan Management Review Fall, s. 51-63.

2. Geng D., 2007, GMvs. Toyota: By the Numbers. http://www.npr.org/news/specials/gmvstoyota/ (sierpień 2007 r.).

3. Hamel G., Prahalad C.K., 1994, Competing for the Future, Harvard Business School Press, Boston.

4. Hart Ch.W., 2007, Beating the Market with Customer Satisfaction, HBR, March 1.

5. Janman N., 2000, Real Estate Mistakes, Rowley Publications, Sydney.

6. Kamiński K., 2006, Stodkie życie cukiernika, ,, Angora”, nr 48 (858).

7. Langfield-Smith K., 1998, Developing Co-operative Buyer Supplier Relationships: A Case Study of Toyota, "Journal of Management Studies", May, Volume 35, Issue 3.

8. Michalik B., 2007, Sztuka negocjacji, www.nf.pl (lipiec 2007 r.).

9. Peters T., 1992, Liberation Management Macmillan, London. 
10. Searle J., 2007, Return of Service BRW, March 1-7 2007.

11. Shawcross M., 1997, Murdoch -Revised and Updated, Simon and Schuster, New York.

12. Swift B., 2007, Aussie tries to force brokers into line, "The Australian Financial Review", 9 March.

13. Tandukar A., 2005, Real Values, Real Profits, BRW, September 8-14.

14. Thompson J., 2007, The Next Gear, BRW, March 1-7.

15. Washington S., 2005, Trujillo's Service Faults, "Business Review Weekly", September 8-14.

\section{Still win-win: Pragmatism of Entrepreneurship, Or a New Look at the Negotiations}

All the entrepreneurs have to face the fundamental question: Is the business ethics contrary to the nature? This question is not often asked in academic writings on ethics, but clearly an important one. The paper attempts to review impact of relations between entrepreneurs and key stakeholders and the business bottom line. The results clearly show that a strategy based on mutually beneficial relations is not only socially desired, but brings also positive financial results. Relations with suppliers, staff and clients have been particularly closely considered. It has been suggested, that research review shall be considered in the teaching of entrepreneurship but also by managers, boards and investors. 